\title{
Halothane and $\gamma$-Aminobutyric Acid in Cultured Cells of Nervous System Origin
}

\author{
MICHAEL L. NAHRWOLD ${ }^{1}$ WILLIAM H. HESS ${ }^{2}$ AND DELIA R. BETHELL ${ }^{2}$ \\ ${ }^{1}$ Department of Anesthesiology. The University of Michigan Medical Center, \\ Ann Arbor, MI 48109 \\ and \\ ${ }^{2}$ Department of Anesthesiology, Milton S. Hershey Medical Center, The Pennsylvania State University, \\ Hershey, PA 17033
}

\begin{abstract}
NAHRWOLD, M. L., W. H. HESS AND D. R. BETHELL. Halothane and $\gamma$-aminobutyric acid in cultured cells of nervous swstem origin. BRAIN RES. BULL. 5: Suppl. 2,477-483, 1980.-C-1300 neuroblastoma and C-6 astrocytoma cells in culture were utilized as models of $\gamma$-aminobutyric acid (GABA) metabolism in neurons and glia, respectively. Both cell lines were exposed to $0,0.7,1.0,1.7$, or $3.0 \%$ halothane at $37 \mathrm{C}$ and $\mathrm{pH} 7.1$ with glucose as substrate. Cellular viability was unaffected by the anesthetic in either cell line. Halothane did not alter cellular content of GABA in C-1300 neuroblastoma cells. However, 0.7 and $1.0 \%$ halothane lowered the levels of GABA in C-6 astrocytoma cells which had been provided with fresh medium 18-21 hr prior to anesthetic exposure (fed cells). This response was absent following treatment with 1.7 or 3.0\% halothane. Efflux of GABA was decreased by $1 \%$ halothane in $\mathrm{C}-1300$ neuroblastoma cells which had not received fresh medium for 48 to $72 \mathrm{hr}$ (starved cells). This response was ahsent in fed cells. In contrast, starved C-6 astrocytoma cells exhibited an increase in GABA efflux following exposure to all concentrations of halothane. Similar results were observed in fed cells treated with $1 \%$ and $3 \%$ halothane. These data support the results of previous studies showing an increase in the GABA content of rat brain slices following exposure to halothane; however, they suggest that glia rather than neurons are the major source of the increased levels of GABA.
\end{abstract}

Halothane $\quad \gamma$-Aminobutyric acid $\quad$ C-1300 Neuroblastoma cells $\quad C-6$ Astrocytoma cells

THE MECHANISM by which the inhalation anesthetic, halothane, causes general anesthesia is unknown. An elegant hypothesis which involves alterations in $\gamma$-aminobutyrate (GABA) metabolism has been offered by Cheng and Brunner [9]. These investigators found an increase in GABA content of rat cerebral cortex slices following exposure to halothane. They postulated that the metabolic alteration responsible for this effect was localized in the nerve endings rather than glia. However, their data were based on techniques utilizing radioactively labeled precursors to delineate metabolic pools associated with the two cell types. They did not have direct morphologic evidence for their results.

To investigate the interaction between glia and neurons as regards GABA metabolism, it would be desirable to have pure, isolated preparations of both cell types. Separation of these two fractions is difficult and time consuming, and the resultant preparations are often contaminated with undesirable cell types [2]. Therefore, neurobiologists have increasingly turned to the use of tissue culture derived from nervous system tumors to examine the metabolic properties of neuron- or glia-like cells. Two of the more popular cell lines are C- 1300 neuroblastoma and C-6 astrocytoma. Although these cultures are neoplastic, they have been shown to retain many differentiated features of their normal counterparts.

C-1300 neuroblastoma cells were derived from a mouse paravertebral tumor and they have "biochemical, morphological, and electrophysiological properties indicating unequivocal neuronal differentiation" [34]. When cultured in Petri dishes, C-1300 cells attach to the surface and extend neuron-like processes termed "neurites", and they morphologically resemble intact neurons [34, 46, 49]. The cells contain the biochemical apparatus necessary for neurotransmitter synthesis, storage and degradation $[1,6,8,15$, 46,49 ], and they exhibit an action potential following electri$\mathrm{cal}$, ionic or neurohumoral stimulation $[6,33,34,35,36,37$, $41,49,52]$. C- 1300 cells also resemble neurons in regard to their ganglioside composition [12], cell surface antigens [47], lactate dehydrogenase isoenzymes [51], adenosine-activated adenyl cyclase [42], and adenosine triphosphatase activity [26].

C-6 astrocytoma cells originated from a rat glial tumor [5] and they were selected for their synthesis of the important glial marker, S-100 protein $[19,30,44]$. Their morphologic features resemble those of intact glia $[5,38]$, and they contain astrocyte-specific [2] glial fibrillary acidic protein [7], the glial marker, $2^{\prime}, 3^{\prime}$-cyclic nucleotide-3'-phosphohydrolase, $[43,53]$, proteolipid and myelin basic proteins [53], and cortisol-induced glycerol phosphate dehydrogenase $[13,14]$. Other characteristics of C-6 cells which are similar to those of glia include adenosine triphosphatase activity [26], glucose uptake [32], sodium and potassium transport $[28,29]$, and membrane potential $[28,29]$.

The availability of both cell lines provides a unique opportunity to assign metabolic events to specific cell types. Therefore, we exposed C-1300 neuroblastoma and C-6 astrocytoma cells to halothane in an effort to further charcterize the alterations in GABA metabolism caused by halothane. Support for this approach was provided by the 


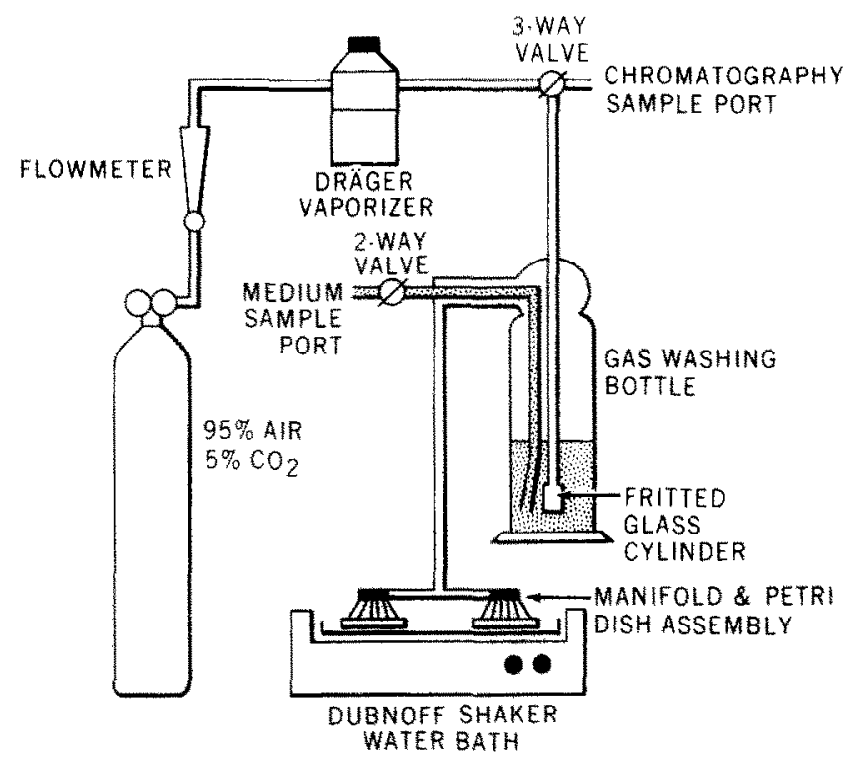

FIG. 1. Anesthesia circuit for exposing cultures to halothane. PBS-G equilibrated with halothane could be removed via the medium sample port. Details of the manifold and Petri dish assembly are shown in Fig. 2.

fact that both cell lines resemble intact neurons and glia in regard to GABA metabolism $[11,22,27,48]$.

\section{METHOD}

\section{Materials}

Chemicals were purchased from Sigma Chemical Co., St. Louis, MO 63178 and were of reagent grade or better. Tissue culture media and phosphate-buffered saline were obtained from the Grand Island Biological Supply Co., Grand Island, NY 14072 or from the Microbiology Department at the M. S. Hershey Medical Center.

\section{Cell Cuitures}

C-1300 neuroblastoma and C-6 astrocytoma certified cell lines were obtained from the American Type Culture Collection, Rockville, MD 20852. C-1300 cells were grown in Dulbecco's modified Eagle's medium, while C-6 cells were grown in Ham's F-10 medium as described in detail previously [32]. Both media contained sodium bicarbonate, $10 \%$ fetal calf serum (not inactivated), penicillin and streptomycin. Stock cultures were maintained in $75 \mathrm{~cm}^{2}$ tissue culture flasks at $37 \mathrm{C}$ in a humidified atmosphere of $95 \%$ air $-5 \% \mathrm{CO}_{2}$. Experiments were performed on monolayer subcultures grown in six-well Petri dishes (FB-6TC, Linbro Scientific Co., New Haven, CT 06511).

\section{Exposure to Halothane}

Cultures in six-well Petri dishes were washed three times with $1 \mathrm{ml}$ of Dulbecco's phosphate-buffered saline containing $5.56 \mathrm{mM}$ glucose (PBS-G). The cells were then exposed to halothane using the anesthesia circuit outlined in Fig. 1. A mixture of $95 \%$ air - $5 \% \mathrm{CO}_{2}$ passed through a flowmeter and
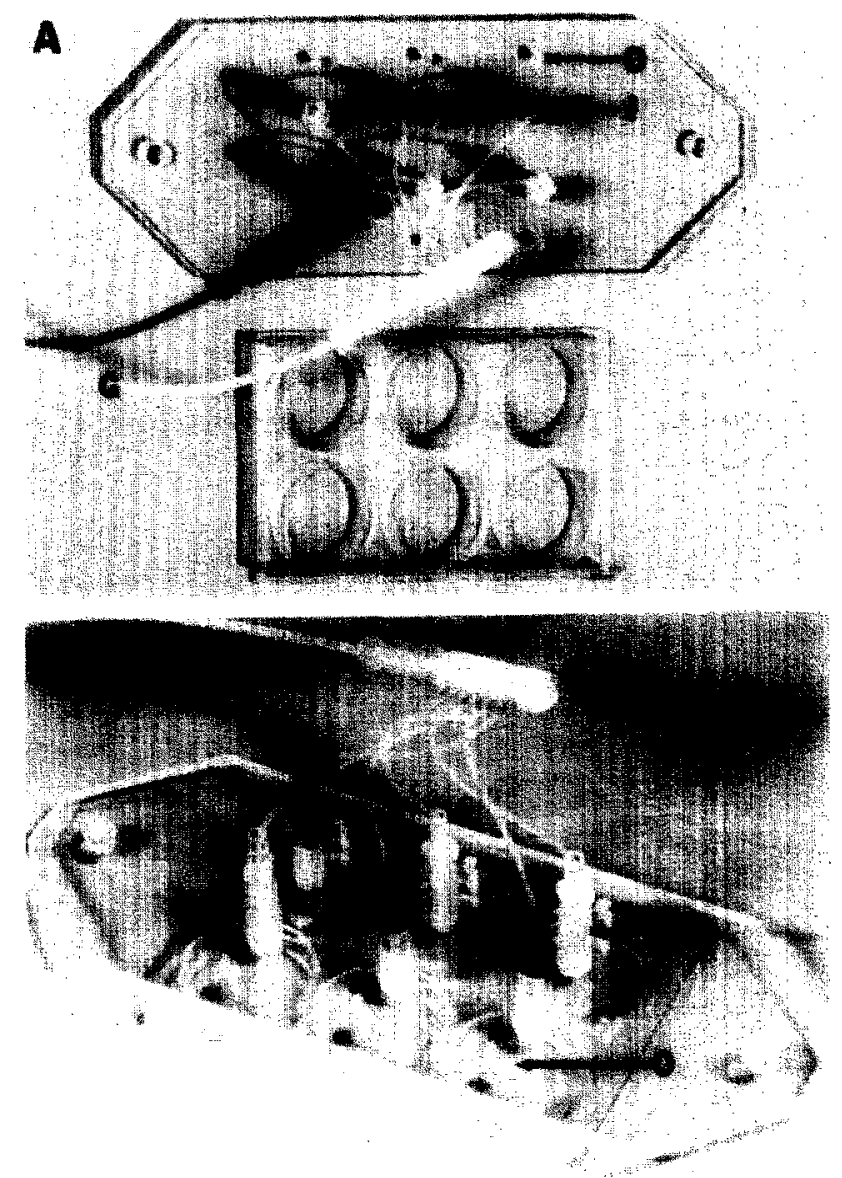

FIG. 2. Culture dish and manifold assembly. Teflon tubing (G) passes from the gas washing bottle (Fig. 1) to a 6-way manifold which directs the flow of gas to each Petri dish well via an inlet port (I). The flow of gas escapes through an outlet port (O). Preequilibrated media could be added to each well with a syringe and needle inserted through the outlet port. A. Disassembled view. B, Assembled view.

a Dräger halothane vaporizer to a gas washing bottle containing PBS-G. After bubbling through the PBS-G, the gas was directed to manifold assemblies covering the Petri dishes. Use of the gas washing bottle permitted the preparation of a supply of PBS-G tonometered with the gas mixture under study and insured that the flow of gas to the culture dishes was well humidified.

Details of a manifold assembly are shown in Fig. 2. Each manifold was constructed such that an individual stream of gas was directed to each culture dish well via an inlet port. An outlet port for each well remained open to atmosphere. At the beginning of a period of equilibration, about $150 \mathrm{ml}$ of PBS-G in the gas washing bottle was pre-equilibrated with gas at a flow of $800 \mathrm{ml} / \mathrm{min}$ for $5 \mathrm{~min}$. A supply of preequilibrated PBS-G was then obtained from the gas washing bottle with a glass syringe. The culture dishes were placed under the manifolds and $1 \mathrm{ml}$ of PBS-G was injected through the outlet port into each well using the syringe fitted with a stainless steel needle. Gas mixture was then allowed to flow across each well at $10 \mathrm{ml} / \mathrm{min}$ per well for a $30 \mathrm{~min}$ period of equilibration. During this time, the dishes were gently shak- 
en and maintained at $37 \mathrm{C}$ in a Dubnoff shaker water bath. Usually two six-well dishes were treated simultaneously, one containing each cell line.

Halothane concentrations were monitored with gas chromatography and expressed as \% of a standard atmosphere. Concentrations utilized were 0 (control), $0.7,1.0,1.7$ and $3.0 \%$.

\section{Viability Studies}

To insure that halothane was not cytotoxic, two-day-old subcultures of C-1300 and C-6 cells were exposed to anesthetic as described above. Following incubation, the monolayers were covered with trypan blue dye and examined under a phase-contrast microscope. At least 100 cells per Petri dish well were counted and the proportion of cells taking up the dye was recorded as being dead [16].

\section{GABA Experiments}

Seven- or eight-day-old subcultures were exposed to halothane as above. After $30 \mathrm{~min}$, the media were decanted and saved. The cells were then extracted with $0.5 \mathrm{ml}$ of cold $0.3 \mathrm{~N}$ perchloric acid, and the extracts immediately neutralized. Cellular protein was solubilized in $1 \mathrm{~N} \mathrm{NaOH}$ to permit measurcment with the Lowry method [31].

Medium and cellular GABA levels were determined with two fluorometric enzymatic techniques using GABAse (Sigma) [40]. Cellular levels of GABA were measured in the neutralized perchloric acid extracts and expressed as nmoles $/ \mathrm{mg}$ cellular protein. Levels of GABA in the media were utilized as an index of efflux of GABA and were expressed as nmoles or pmoles $/ 30 \mathrm{~min} / \mathrm{mg}$ protein

\section{Nutritional Status of Cells}

To assess the effect of glycogen stores on the interaction between halothane and GABA metabolism, GABA experiments were performed on cells maintained in either a starved or fed nutritional state. Starved cells did not have a change of medium for 48 to $72 \mathrm{hr}$ prior to exposure to halothane. This treatment results in complete depletion of glycogen stores in C-6 cells [39]. Fed cells received fresh medium 18 to $21 \mathrm{hr}$ before halothane treatment.

\section{Statisticis}

Data were grouped according to cell line and nutritional state of the cells. For each of these groups, a dose-response curve was constructed. Differences within these groups were examined by analysis of variance [4]. When such determinations were significant $(p<0.05)$, differences between control and experimental points were sought using Student's unpaired $t$-test $[4]$.

\section{RESULTS}

\section{Viability Studies}

Halothane did not exhibit a significant cytotoxic effect on either cell line. After a $30 \mathrm{~min}$ exposure, the largest proportion of dead cells was about $7 \%$. There was no dose-response correlation between high halothane concentrations and increased cell death.

\section{GABA Experiments with C-1300 Neuroblastoma Cells}

Figure 3 shows that halothane did not alter the cellular

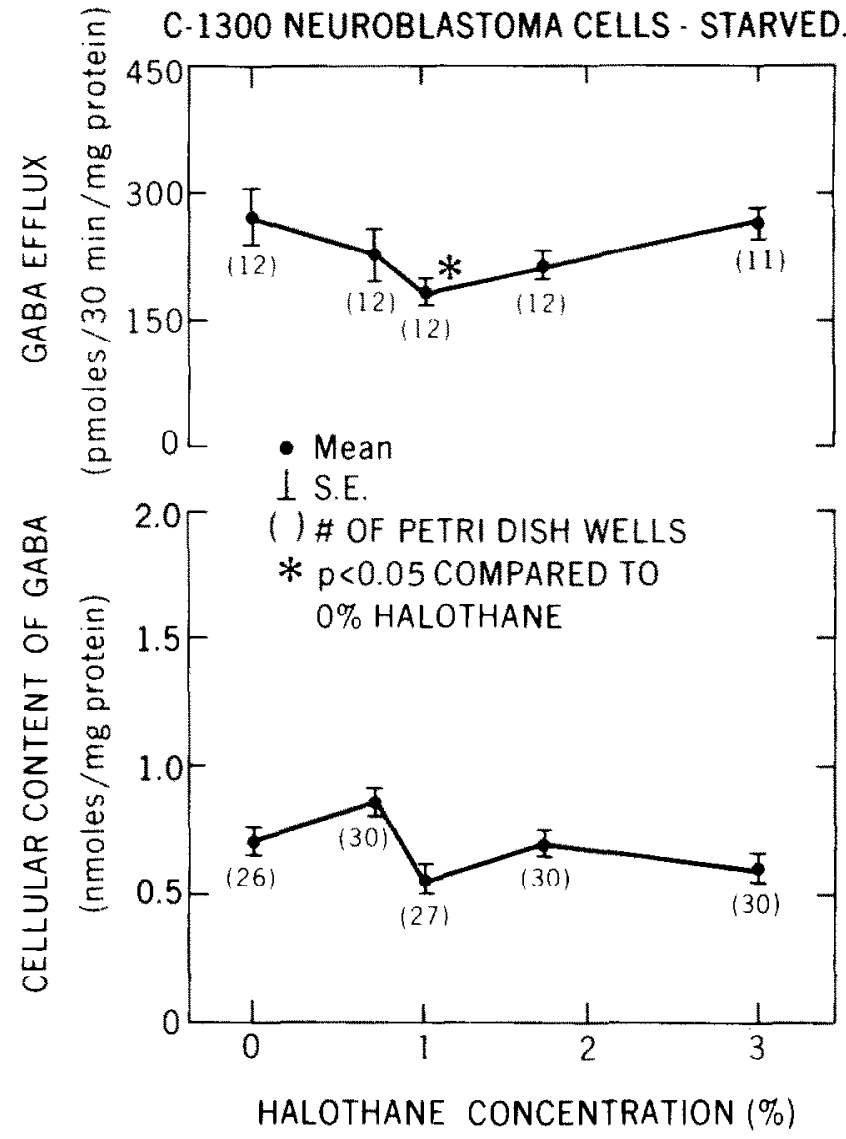

FIG. 3. Effect of halothane on cellular levels and efflux of GABA. Starved C-1300 neuroblastoma cells.

content of GABA in C- 1300 neuroblastoma cells which had been depleted of their glycogen stores (starved). However, treatment with $1 \%$ halothane inhibited efflux of GABA from the cells. Higher and lower halothane concentrations had no effect.

Cellular content of GABA was also not affected by halothane when similar preparations were studied in a fed nutritional state (Fig. 4). However, the depression of GABA efflux seen in starved cells following $1 \%$ halothane treatment was no longer apparent in the fed cells.

\section{GABA Experiments Using C-6 Astrocytoma Cells}

In starved C-6 astrocytoma cells, as with C- 1300 cells, cellular content of GABA was not affected by halothane (Fig. 5). In contrast, efflux of GABA was nearly doubled by treatment with $0.7 \%$ halothane. Higher concentrations of the anesthetic produced somewhat smaller elevations in GABA efflux.

The accentuation of GABA efflux caused by halothane in starved cells was somewhat blunted in fed cells and it was significant only at $1 \%$ and $3 \%$ halothane (Fig. 6). Cellular content of GABA in fed cells was decreased by exposure to 0.7 and $1 \%$ halothane.

\section{DISCUSSION}

The concept of using tissue cuiture to study the metabolic 


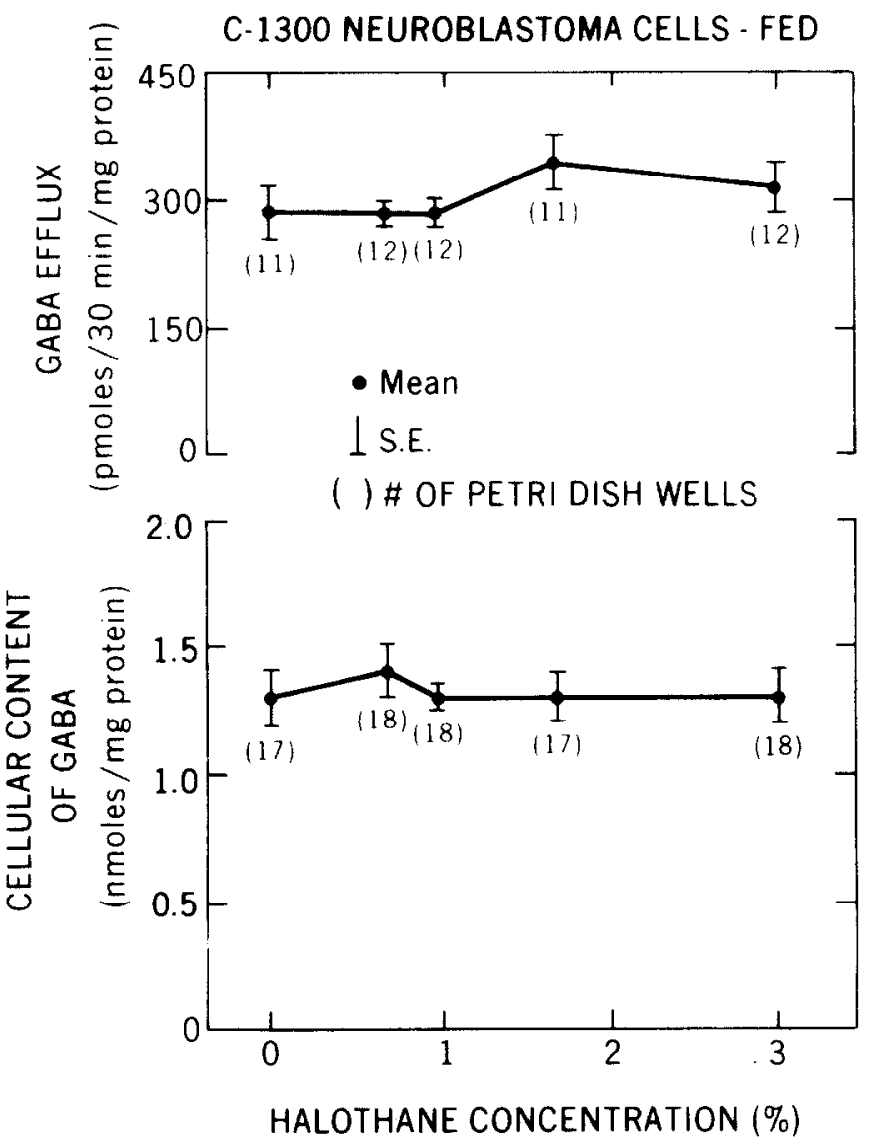

FIG. 4. Effect of halothane on cellular levels and efflux of GABA. Fed C-1300 neuroblastoma cells.

effects of volatile anesthetics is not new. Jackson utilized mammalian hepatoma cells to examine the effects of halothane on cell replication and DNA synthesis $[24,25]$. Similar experiments were performed by Ishii and Corbascio utilizing Morris rat hepatoma cells [23], and the interaction between volatile anesthetics and metabolic patterns of mouse heteroploid and sarcoma I cells was examined in Fink's laboratory $[17,18]$. Although cultures used by these investigators were mammalian, the results could not be extrapolated to normal cells in the intact organism.

Hinkley and Telser utilized the C-1300 neuroblastoma cell line to examine the effects of halothane on morphological differentiation $[20,21]$. They found that halothane caused reversible inhibition of neurite extension and microspike formation. In addition, Seager showed that halothane increased the levels of adenosine 3', 5'-cyclic monophosphate in $\mathrm{C}-1300$ cells [50]. Although these investigators took advantage of the fact that $\mathrm{C}-1300$ cells resemble neurons, none of them exploited the C-6 astrocytoma cell system to seek differential effects of the anesthetic on two distinct cell types of nervous system origin.

The fact that both cell lines resemble their normal counterparts in regard to morphology, differentiation, metabolic patterns, electrophysiology, membrane properties and neurotransmitter synthesis and storage is well documented. However, since the cells are neoplastic, some differences between them and normal neurons and glia might be expected to occur. Therefore, it is essential that the property of

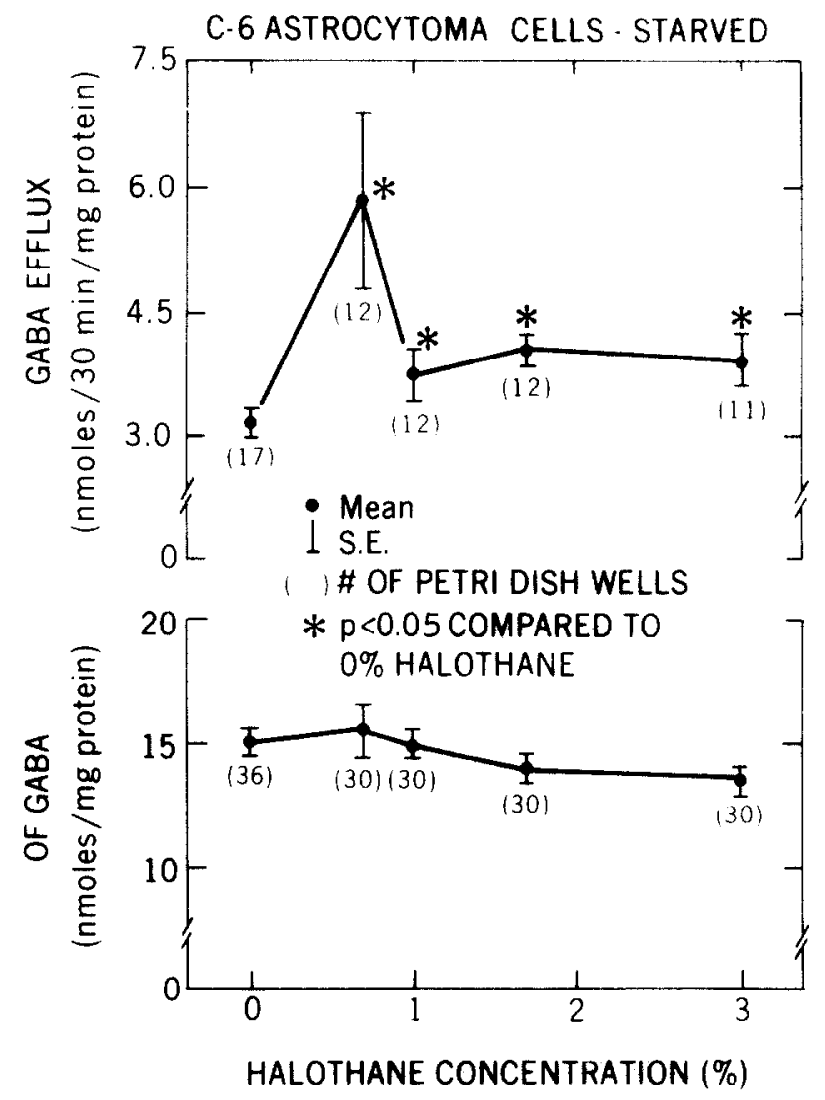

FIG. 5. Effect of halothane on cellular levels and efflux of GABA. Starved C-6 astrocytoma cells.

the cells being studied is known to resemble its counterpart in normal nervous system.

C-1300 cells possess high activities of glutamate dehydrogenase [11], an essential enzyme for synthesis of glutamic acid which is the substrate required for GABA synthesis [45]. GABA can be formed by C-1300 cells utilizing putrescine as a precursor [27] and a metabolic pathway known to be present in mouse brain [45]. The activities of glutamate decarboxylase, GABA transaminase, succinic semialdehyde dehydrogenase, and glutamate dehydrogenase in both cell lines are different from those present in mouse cerebral cortex. However the concentrations of GABA, glutamate and $\alpha$-kelogtutarate are quite similar [40].

Both cell lines take up GABA from the surrounding medium by a high-affinity, carrier-mediated transport system and a second, apparently non-saturable, process which may represent diffusion. Similar accumulation of GABA has been demonstrated in glial cells and in synaptosomal preparations [22]. The synthesis, uptake, and efflux of GABA by C-6 cells has been detailed by Schrier et al. [48]. They demonstrated pyridoxal-dependent synthesis of GABA and sodiumdependent uptake of the neurotransmitter similar to that present in partially purified glial preparations. In addition, the astrocytoma cells were capable of excreting GABA into the extracellular medium. Thus, at least qualitatively, GABA metabolism in the two cell lines is not unlike that of intact glia and neurons.

A "receptor unit" including receptor binding sites for 

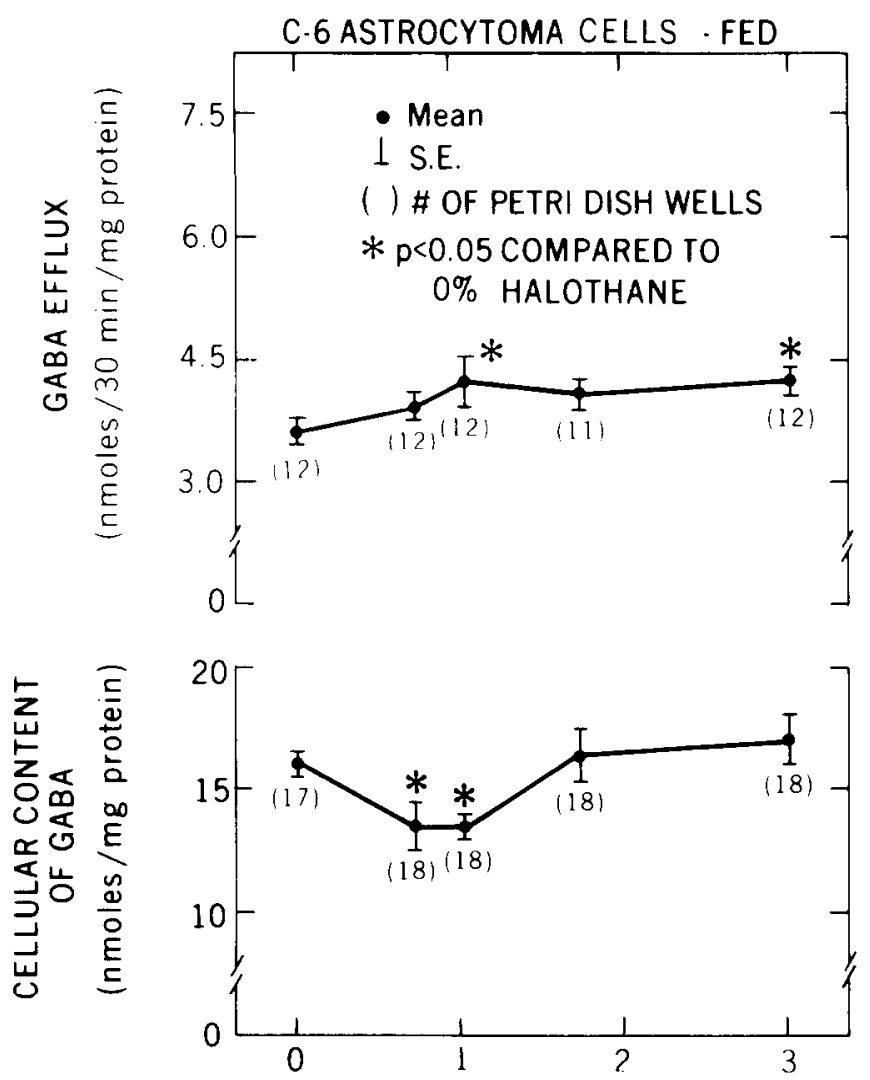

HALOTHANE CONCENTRATION (\%)

FIG. 6. Effect of halothane on cellular levels and efflux of GABA. Fed C-6 astrocytoma cells.

GABA and benzodiazepines has been demonstrated in membrane preparations of both cell lines. This lends credence to the concept that the cells may be used as models of drug-receptor interactions [3].

The present study was designed so that the cell cultures were exposed to conditions of temperature and partial pressures of oxygen and carbon dioxide similar to those present in brain. Particular care was taken to insure that the tension of halothane in the medium surrounding the cells was predictable and remained constant. PBS-G was chosen as the extracellular medium because it provided the cells with a major single source of extracellular carbohydrate. A glucose concentration of $5.56 \mathrm{mM}$ was used because at this level the transport system for glucose is nearly saturated in C-6 cells [32].

Halothane caused minimal alterations of cellular levels of GABA in either C-1300 neuroblastoma cells or C-6 astrocytoma cells, regardless of nutritional state. Thus, it can be inferred that halothane does not interfere with the control mechanisms necessary for maintaining cellular levels of the metabolite. In contrast, a differential effect of halothane on efflux of GABA from the two cell lines was shown. One percent halothane depressed efflux of GABA from starved C-1300 neuroblastoma cells, while all concentrations of halothane accentuated efflux of GABA from starved C-6 astrocytoma cells. Furthermore, alterations in GABA efflux from both cell lines were diminished or absent when the cells had been recently fed.

Conditions similar to those present in the starved cells produce nearly undetectable levels of glycogen in C-6 cells, while conditions corresponding to the fed state produce glycogen levels of about $10 \mathrm{nmoles} / \mathrm{mg}$ of cellular protein. In addition, when starved cells are presented with a fresh supply of glucose, they tend to preferentially re-establish their glycogen stores [39]. One can speculate, then, that in the absence of glycogen stores, perhaps degradation of GABA is diminished in an effort to conserve this neurotransmitter. In the presence of halothane, degradation of GABA might be further inhibited as suggested by Cheng and Brunner $[9,10]$. This would permit GABA to accumulate and be released into the surrounding medium. No data are available on the effect of cell starvation on glycogen stores in C- 1300 neuroblastoma cells. However, results from both cell lines point out that the metabolic response of the cells to halothane is extremely sensitive to the nutritional state of the cells.

Our findings differ in part from those of Cheng and Brunner [9]. The investigators observed an increase in GABA content in rat cerebral cortex slices exposed to halothane. Studies utilizing radioactive substrates suggested that the primary metabolic alteration responsible for these changes occurred in the nerve endings of the slices. The present study showed that halothane causes an increase in GABA efflux from C-6 astrocytoma cells, whether starved or fed. The magnitude of this increase was such that it was not offset by the slight decrease in GABA efflux seen only in the starved neuroblastoma cells. Content of GABA in brain slices is the sum of both cellular and extracellular levels of GABA. 'I 'hus, the net increase in efflux of GABA observed in the present study could be interpreted as supporting the findings of Cheng and Brunner. However, our data suggest that the metabolic event contributing to the elevated levels of GABA caused by halothane occurs in glia rather than neurons.

GABA has been characterized as a putative neurotransmitter with inhibitory properties at the synapse [45]. Our data support the concept that GABA-mediated synaptic inhibition of cerebral activity may occur during halothane anesthesia and that, in addition, the anesthetic may cause a differential metabolic response in various cell types within the nervous system.

\section{ACKNOWLEDGMENTS}

Drs. W. David Lust and Janet V. Passonneau kindly worked out the GABA assay utilized in these experiments. Ms. Alice Armstrong provided expert technical assistance. 


\section{REFERENCES}

1. Amano, T., E. Richelson and M. Nirenberg. Neurotransmitter synthesis by neuroblastoma clones. Proc. natn. Acad. Sci. U.S.A. 69: 258-263, 1972.

2. Appel, S. H. and E. D. Day. Cellular and subcellular fractionation. In: Basic Neurochemistry, edited by G. J. Siegel, R. W. Albers, R. Katzman and B. W. Agranoff. Boston: Little, Brown and Company, 1976, pp. 34-59.

3. Baraldi, M., A. Guidotti, J. P. Schwartz and E. Costa. GABA receptors in clonal cell lines: a model for study of benzodiazepine action at molecular level. Science 205: 821-823, 1979.

4. Batson, H. C. An Introduction to Statistics in the Medical Sciences. Minneapolis: Burgess, 1956.

5. Benda, P., J. Lightbody, G. Sato, L. Levine and W. Sweet. Differentiated rat glial cell strain in tissue culture. Science 161: 370-371, 1968.

6. Benjamins, J. A. and G. M. McKhann. Development, regeneration, and aging. In: Basic Neurochemistry, edited by G. J. Siegel, R. W. Albers, R. Katzman and B. W. Agranoff. Boston: Little, Brown and Company, 1976, pp. 365-387.

7. Bissell, M. G., L. F. Eng, M. M. Herman, K. G. Bensch and L. E. M. Miles. Quantitative increase of neuroglia-specific GFA protein in rat C-6 glioma cells in vitro. Nature 255: 633-634, 1975.

8. Breakefield, X. O., E. A. Neale, J. H. Neale and D. M. Jacobowitz. Localized catecholamine storage associated with granules in murine neuroblastoma cells. Brain Res. 92: 237-256, 1975.

9. Cheng, S. C. and E. A. Brunner. A neurochemical hypothesis for halothane anesthesia. Anesth. Analg. (Cleve) 54: 242-246, 1975.

10. Cheng, S. C. and E. A. Brunner. Two neurotransmitters in brain slices. In: Molecular Mechanisms of Anesthesia, edited by B. R. Fink. New York: Raven Press, 1975, pp. 509-520.

11. Ciesielski-Treska, J., P. Mandel, G. Tholey and B. Wurtz. Enzymatic activities modified during multiplication and differentiation of neuroblastoma cells. Nature New Biol. 239: 180 $181,1972$.

12. Dawson, G. and A. C. Stoolmiller. Comparison of the ganglioside composition of established mouse neuroblastoma cell strains grown in vivo and in tissue culture. J. Neurochem. 26: $225-226,1976$.

13. de Vellis, J. and G. Brooker. Induction of enzymes by glucocorticoids and catecholamines in a rat glial cell line. In: Tissue Culture of the Nervous System, edited by G. Sato. New York: Plenum Press, 1973, pp. 231-245.

14. de Vellis, J. and G. Kukes. Regulation of glial cell functions by hormones and ions: a review. Tex. Rep. Biol. Med. 31: 271-293, 1973.

15. Donnelly, C. H., E. Richelson and D. L. Murphy. Properties of monoamine oxidase in mouse neuroblastoma N1E-115 cells. Biochem. Pharmac. 25: 1639-1643, 1976.

16. Evans, H. M. and W. Schulemann. The action of vital stains belonging to the benzidine group. Science 39: 443-454, 1914

17. Fink, B. R. and G. E. Kenny. Metabolic effects of volatile anesthetics in cell culture. Anesthesiology 29: 505-516, 1968.

18. Fink, B. R., G. E. Kenny and W. E. Simpson, III. Depression of oxygen uptake in cell culture by volatile, barbiturate and local anesthetics. Anesthesiology 30: 150-155, 1969.

19. Herschman, H. R., B. P. Grauling and M. P. Lerner. Nervous system-specific proteins in cultured neural cells. In: Tissue Culture of the Nervous System, edited by G. Sato. New York: Plenum Press, 1973, pp. 187-202.

20. Hinkley, R. E. and A. G. Telser. The effects of halothane on cultured mouse neuroblastoma cells. I. Inhibition of morphological differentiation. J. Cell Biol. 63: 531-540, 1974.

21. Hinkley, R. E. and A. G. Telser. The effects of halothane on microfilamentous systems in cultured neuroblastoma cells. In: Molecular Mechanisms of Anesthesia, edited by B. R. Fink. New York: Raven Press, 1975, pp. 103-120.
22. Hutchison, H. T., K. Werrbach, C. Vance and B. Haber. Uptake of neurotransmitters by clonal lines of astrocytoma and neuroblastoma in culture. I. Transport of $\gamma$-aminobutyric acid. Brain Res. 66: 265-274, 1974.

23. Ishii, D. N. and A. N. Corbascio. Some metabolic effects of halothane on mammalian tissue culture cells in vitro. Anes. thesiology 34: 427-438, 1971.

24. Jackson, S. H. The metabolic effects of halothane on mammalian hepatoma cells in vitro: 1. Inhibition of cell replication. Anesthesiology 37: 489-492, 1972.

25. Jackson, S. H. The metabolic effects of halothane on mammalian hepatoma cells in vitro: II: Inhibition on DNA synthesis. Anesthesiology 39: 405-409, 1973.

26. Kimelberg, $\mathrm{H}$. K. Active potassium transport and $\left(\mathrm{Na}^{+}+\mathrm{K}^{+}\right)$ ATPase activity in cultured glioma and neuroblastoma cells. $J$. Neurochem. 22: 971-976, 1974.

27. Kremzner, L. T., J. M. Hiller and E. J. Simon. Metabolism of polyamines in mouse neuroblastoma cells in culture: formation of GABA and putreanine. J. Neurochem. 25: 889-894, 1975.

28. Kukes, G., R. Elul and J. de Vellis. The ionic basis of the membrane potential in a rat glial cell line. Brain Res. 104: 71-92, 1976.

29. Kukes, G., J. de Vellis and R. Elul. A linked active transport system for $\mathrm{Na}^{+}$and $\mathrm{K}^{+}$in a glial cell line. Brain Res. 104: 93$105,1976$.

30. Labourdette, G. and A. Marks. Synthesis of S-100 protein in monolayer cultures of rat-glial cells. Eur. J. Biochem. 58: 73-79, 1975.

31. Lowry, O. H., N. J. Rosebrough, A. L. Farr and R. J. Randall Protein measurement with the Folin phenol reagent. $J$. biol. Chem. 193: 265-275, 1951.

32. Lust, W. D., J. P. Schwartz and J. V. Passonneau. Glycolytic metabolism in cultured cells of the nervous system. I. Glucose transport and metabolism in the C-6 glioma cell line. Molec. Cell. Biochem. 8: 169-176, 1975.

33. Nelson, P. G. Electrophysiological studies of normal and neoplastic cells in tissue culture. In: Tissue Culture of the Nervous System, edited by G. Sato. New York: Plenum Press, 1973, pp. $135-160$.

34. Nelson, P. G. Nerve and muscle cells in culture. Physiol. Rev. 55: $1-61,1975$.

35. Nelson, P., W. Ruffner and M. Nirenberg. Neuronal tumor cells with excitable membranes grown in vitro. Proc. natn. Acad. Sci. U.S.A. 64: 1004-1010, 1969.

36. Nelson, P. G., J. H. Peacock and T. Amano. Responses of neuroblastoma cells to iontophoretically applied acetylcholine. J. Cell Physiol. 77: 353-362, 1971.

37. Nelson, P. G., J. H. Peacock, T. Amano and J. Minna. Electrogenesis in mouse neuroblastoma cells in vitro. $I$. Cell Physiol. 77: 337-352, 1971.

38. Oey, J. Noradrenaline includes morphological alterations in nucleated and enucleated rat C-6 glioma cells. Nature, (Lond.) 257: 317-319, 1975.

39. Passonneau, J. V. and S. K. Crites. Regulation of glycogen metabolism in astrocytoma and neuroblastoma cells in culture. J. biol. Chem. 251: 2015-2022, 1976.

40. Passonneau, J. V., W. D. Lust and S. K. Crites. Studies on the GABAergic system in astrocytoma and ncuroblastoma cells in culture. Neurochem. Res. 2: 605-617, 1977.

41. Peacock, J. H. and P. G. Nelson. Chemosensitivity of mouse neuroblastoma cells in vitro. J. Neurobiol. 4: 363-374, 1973.

42. Penit, J., J. Huot and S. Jard. Neuroblastoma cell adenylate cyclase: direct activation by adenosine and prostaglandins. $J$. Neurochem. 26: 265-273, 1976.

43. Pfeiffer, S. E. Clonal lines of glial cells. In: Tissue Culture of the Nervous System, edited by G. Sato. New York: Plenum Press, 1973, pp. 203-230.

44. Pfeiffer, S. E., H. R. Herschman, J. Lightbody and G. Sato. Synthesis by a clonal line of rat glial cells of a protein unique to the nervous system. J. Cell Physiol. 75: 329-340, 1970. 
45. Roberts, E. and R. Hammerschlag. Amino acid transmitters. In: Busic Neurochemistry, edited by G. J. Siegel, R. W. Albers, R. Katzman and B. W. Agranoff. Boston: Little, Brown and Company, 1976, pp. 218-245

46. Rosenberg, R. N. Regulation of neuronal enzymes in cell culture. In: Tissue Culture of the Nervous System, edited by G. Sato. New York: Plenum Press, 1973, pp. 107-134.

47. Schachner, M. Serologically demonstrable cell surface specificities on mouse neuroblastoma C-1300. Neture Ne' Biol. 243: $117-119,1973$.

48. Schrier, B. K. and E. J. Thompson. On the role of glial cells in the mammalian nervous system. $J$. biol. Chem. 249: 1769-1780, 1974.

49. Schubert, D.. A. J. Harris, S. Heinemann, Y. Kidokoro, J. Patrick and J. H. Steinbach. Differentiation and interaction of clonal cell lines of nerve and muscle. In: Tissue Culute of the Nerious System, edited by G. Sato. New York: Plenum Press, 1973, pp. 55-86.
50. Seager, O. A. Effects of anesthetics on cyclic AMP levels in mouse neuroblastoma cells in culture. In: Molecular Mech anisms of Anesthesia, edited by B. R. Fink. New York: Raven Press, 1975, pp. 471-484.

51. Tholey, G., B. Wurtz, J. Ciesielski-Treska and P. Mandel. Lactate dehydrogenase in neuroblastoma clones. J. Neurochem. 23: 1083-1084, 1974.

52. Tuttle, $J$ and $F$. Richelson. Ionic excitation of a clone of mouse neuroblastoma. Brain Res. 84: 129-135. 1975.

53. Volpe, J. J., K. Fujimoto. J. C. Marasa and H. C. Agrawal. Relation of C-6 glial cells in culture to myelin, Biochem. J. 152: $701-703,1975$. 